Research for Development

Paolo Pileri

Rossella Moscarelli Editors

Cycling \&

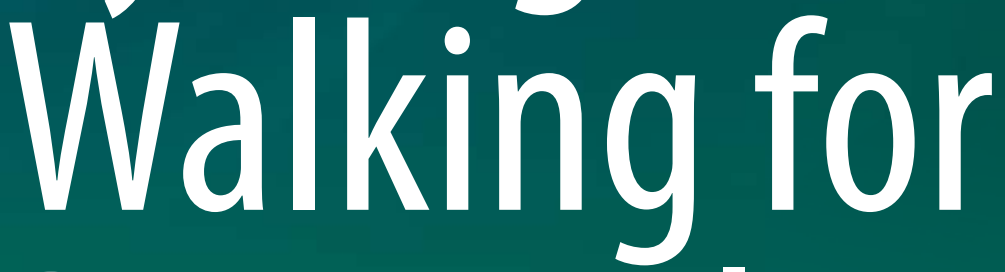

Regional

Development

How Slowness Regenerates Marginal Areas

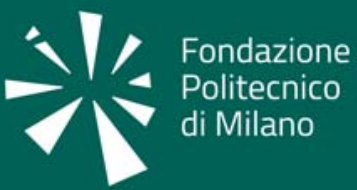

Springer 


\section{Research for Development}

\section{Series Editors}

Emilio Bartezzaghi, Milan, Italy

Giampio Bracchi, Milan, Italy

Adalberto Del Bo, Politecnico di Milano, Milan, Italy

Ferran Sagarra Trias, Department of Urbanism and Regional Planning, Universitat Politècnica de Catalunya, Barcelona, Barcelona, Spain

Francesco Stellacci, Supramolecular NanoMaterials and Interfaces Laboratory (SuNMiL), Institute of Materials, Ecole Polytechnique Fédérale de Lausanne (EPFL), Lausanne, Vaud, Switzerland

Enrico Zio, Politecnico di Milano, Milan, Italy, Ecole Centrale Paris, Paris, France 
The series Research for Development serves as a vehicle for the presentation and dissemination of complex research and multidisciplinary projects. The published work is dedicated to fostering a high degree of innovation and to the sophisticated demonstration of new techniques or methods.

The aim of the Research for Development series is to promote well-balanced sustainable growth. This might take the form of measurable social and economic outcomes, in addition to environmental benefits, or improved efficiency in the use of resources; it might also involve an original mix of intervention schemes.

Research for Development focuses on the following topics and disciplines:

Urban regeneration and infrastructure, Info-mobility, transport, and logistics, Environment and the land, Cultural heritage and landscape, Energy, Innovation in processes and technologies, Applications of chemistry, materials, and nanotechnologies, Material science and biotechnology solutions, Physics results and related applications and aerospace, Ongoing training and continuing education.

Fondazione Politecnico di Milano collaborates as a special co-partner in this series by suggesting themes and evaluating proposals for new volumes. Research for Development addresses researchers, advanced graduate students, and policy and decision-makers around the world in government, industry, and civil society.

\section{THE SERIES IS INDEXED IN SCOPUS}

More information about this series at http://www.springer.com/series/13084 
Paolo Pileri · Rossella Moscarelli Editors

\section{Cycling \& Walking for Regional Development}

How Slowness Regenerates Marginal Areas

黛 Springer 


\section{Editors}

Paolo Pileri

Dipartimento di Architettura e Studi Urbani

Politecnico di Milano

Milan, Italy
Rossella Moscarelli

Dipartimento di Architettura e Studi Urbani

Politecnico di Milano

Milan, Italy
ISSN 2198-7300

Research for Development

ISBN 978-3-030-44002-2

https://doi.org/10.1007/978-3-030-44003-9
ISSN 2198-7319 (electronic)

ISBN 978-3-030-44003-9 (eBook)

\section{(C) Springer Nature Switzerland AG 2021}

This work is subject to copyright. All rights are reserved by the Publisher, whether the whole or part of the material is concerned, specifically the rights of translation, reprinting, reuse of illustrations, recitation, broadcasting, reproduction on microfilms or in any other physical way, and transmission or information storage and retrieval, electronic adaptation, computer software, or by similar or dissimilar methodology now known or hereafter developed.

The use of general descriptive names, registered names, trademarks, service marks, etc. in this publication does not imply, even in the absence of a specific statement, that such names are exempt from the relevant protective laws and regulations and therefore free for general use.

The publisher, the authors and the editors are safe to assume that the advice and information in this book are believed to be true and accurate at the date of publication. Neither the publisher nor the authors or the editors give a warranty, expressed or implied, with respect to the material contained herein or for any errors or omissions that may have been made. The publisher remains neutral with regard to jurisdictional claims in published maps and institutional affiliations.

This Springer imprint is published by the registered company Springer Nature Switzerland AG

The registered company address is: Gewerbestrasse 11, 6330 Cham, Switzerland 


\title{
Narration of Cultural Heritage as Antifragile Tool
}

\author{
Catherine Dezio
}

\begin{abstract}
In our contemporary, multicultural and globalizing society, what can help a fragile territory and community in the protection of its cultural heritage? While walking through a territory, you can realize how it offers itself as a story in continuous elaboration, able to give back ancient and authentic memories, but also to build new ones that can generate opportunities. In this sense, the ancient and spontaneous practice of narration can become an innovative antifragile tool: as an inclusive action for marginal individuals; as a new protection practice for small museums; as an opportunity that facilitates local development processes of depopulated territories, for tourists but also for communities themselves. After a discussion on the topic of narration and its antifragile abilities, we will describe the case of VENTO crossing Casale Monferrato, a small town in the Italian region of Piedmont. VENTO is a project for a cycle route that crosses northern Italy and hopes to mend the identity weave of depopulated territories, generating jobs through the narrative ability of the slow line.
\end{abstract}

\section{Narrating Cultural Heritage}

"Every stone represented the singular conglomerate of a will, of a memory, sometimes of a challenge. Each building stood on the plan of a dream" (Marguerite Yourcenar, “Memoirs of Hadrian”, 1951). This sentence by Marguerite Yourcenar tells of a significant and profound change in the concept of cultural heritage. From the documentation and protection of cultural heritage, today there is a passage towards heritage as a source of new knowledge. The cultural heritage is no longer intended as an asset in itself, to be preserved or enhanced, but as a source of multiple, integrated, relational information, full of emotion and nostalgia for eras lived or sometimes never lived. This dynamism also constitutes the possibility of identifying cultural heritage where we did not expect it before: outside museums, in unexpected, unknown, forgotten places. Between this new vision and a new user (on one hand

\footnotetext{
C. Dezio $(\varangle)$

Department of Architecture and Urban Studies, Polytechnic of Milan, Milan, Italy

e-mail: catherine.dezio@polimi.it 
increasingly demanding, on the other increasingly ignorant), there is an innovative tool for returning complex content in a simple way: narration. Narration is the tool that accompanies this cognitive revolution, where the understanding is an experience. Since narration entered the museums, it is proving to be not only a flexible and congenial tool for mediation of cultural heritage, but a real resource for citizenship, critical literacy and the regeneration of identity belonging (Brunelli 2011; Bodo et al. 2016). It is about the quote of Yourcenar that tells the memory and the will behind a stone, recalling an image of a space, a story, an emotional load. Transporting this synergy between oral, visual and spatial narration in places means generating new forms of knowledge and communication. The didactic component mixes with the evocative one; the official story intertwines and declines in personal stories; the scientific language is combined with the informal one; the memory contained in museums has the same value as the memory presents in the street. Narration is an innovative but also ancient tool. Humans are creatures of communication: not only our species is a communicating species that uses words to narrate since ancient times, but since ever communication intertwines with emotions, building and refining our intelligence (Longo 2008). Stories reconstruct the world and ourselves in the world, so much that in some cultures the world does not exist before being narrated. It can be said that narration is an activity necessary for man to communicate knowledge to other men and to give sense to past events and objects. So necessary and so simple at the same time. To have a narration it is sufficient a narrator, a story, someone to tell it to. A narrator has information that he chooses to share generously with other individuals (Bernardelli 1999). It is a thread that unites. It is a thread that unites oneself, tracing those "cultural intimacies" (Herzfeld 2011; Zingari 2015), which today are needed to face globalizing models and are claimed as a human right to "cultural existence" (Tornatore 2011; Zagato 2014). It is a thread that unites experience of individuals with a wider community, generating sharing. It is a thread that unites generations of today with past and future generations, acting as a fundamental pedagogical tool for self-awareness ("We are our past", said Henri Bergson). And it is also a thread that unites individual objects and stories, material and immaterial heritage, in their original temporal and spatial location. Through narration takes shape this heritage of memories, which defines a tradition and a cultural identity, individual and collective at the same time. Each narrator is invested with the difficult task of creating a complex narrative world, composed of characters, objects, events, giving them welldefined spatial and temporal coordinates. This is how that Yourcenar's stone acquires meaning, being placed back in its history, telling its origin and the reasons for its essence. Narration is basically a primitive and necessary act. It is necessary to give a sense to the world, a sense that exists before we perceive its presence. 


\section{An Antifragile Tool}

Remembering that the notion of heritage is strongly connected with that of territory and of community, narration could be a versatile tool for a new protection of heritage in contemporary dynamic multicultural societies.

In order to always recognized a value for heritage, it must be able to renew itself, with a new aspect: a social aspect as well as cultural aspect (Salerno 2013). In this sense, narration has the potential to become an antifragile tool. Firstly, it can be antifragile for a new inclusive education. Some categories of users can benefit from the narration of cultural heritage: ordinary people, who have lost awareness of the value of history, and especially young people, who are the first with the task of passing on heritage to the future; migrants, usually excluded from the world of heritage; disabled, who often are unable to access to the variety of culture. These and other fragile actors may be the first beneficiaries of narration. Knowing is the tool to include; learning means being able to remember (Recalcati 2014); memory is the first step towards protection.

In parallel, narration can be antifragile also for territories.

Starting with the first heritage sites, museums, they are called to renew their role, today more than ever. We need active cultural centres, with variable and welcoming borders, which establish a constructive relationship with their visitors and which are able to become key points for territories.

We are talking about the big museums of metropolises, but above all we are talking about the small museums in marginal contexts. Small Italian museums are often unknown, widespread in depopulated territories, but they carry with them stories and identities.

For example, there is the Piccolo Museo del Diario (Small Museum of the Diary), inside the Archivio Diaristico Nazionale (National Diaristic Archive) of Pieve Santo Stefano, a small Tuscan village crossed by the itinerary Via di Francesco. There, Saverio Tutino (journalist and partisan during the Italian Resistance) collected memories and stories of Resistance through personal diaries. In an era where everything is digital, smart, fast, a place where you can touch, read, get lost in personal lives located in history is an extraordinary act, an other act of Resistance.

The 1914-1918 Museo della Guerra (War Museum), in Passo Fedaia in Canazei, meets hikers on the Marmolada glacier, a place of battle between Italian and AustroHungarian troops during the first conflict. Here Andrea Bernardin, an expert on the Great War, has collected 700 objects from the Marmolada mountain. In 2002, he chose to close the family restaurant and set up spaces for a permanent exhibition.

Among the Sienese hills there is the Museo dell'Antica Grancia (Museum of Ancient Grancia), originally built in 1200 as house for pilgrims of the Itinerary Via Francigena. Today is a museum of olive oil and of documentation of the "Grance" (from the ancient Latin "granary"), which tells the story of the ancient peasant life through objects and utensils of everyday life.

These are just some of the many small museums spread throughout Italy and the many forms of narration make them value. It is the narration of an object that finds its 
historical thread, or of an event that has changed the identity of a place. It is also the narration of the story of people who collect, preserve and who do not want to make a memory die. And finally, there is also the relationship between different narrative systems: the scale of object that finds its history in the scale of museum, located on a territory, that also asks to be told.

Donadieu (2013) tells the multiple virtues of narration on territorial scale. The narration can discover buildings that symbolized parts of community life, religious (churches, chapels, sanctuaries) or profane (fortified cities, castles, mills), and through them it can mark the agricultural or forest landscapes as signs of a collective memory (Donadieu 2013). The narration can also use literary, pictorial or photographic works that describe landscapes to discover unknown territories. Or the narration can give voice to the inhabitants, who highlight their memories, placing them back in the thread of history. It is at this level of popular expression that ordinary places are cultivated: fields and gardens rise again because someone's word has identified them, an existential word that sets in motion sufferings and pleasures, frustrations and desires, disappointments and joys.

As many narration as the dimensions of space and time. All of them have the faculty of being antifragile tools for marginalized individuals, small elderly societies, unknown heritage, disappeared memories, depopulated territories, as long as they are guided by the intentionality of a visionary project.

\section{A Narrative Line. The Case of VENTO}

There are territorial projects that work to narrate territories. Cycles routes and paths seem to be created to connect two opposite places, but actually they act as zippers. They are lines that unite: they unite the two edges of territory they cross and they unite the individual and punctual elements. The line of a cycle route is a light thread that "works as a hidden supporting structure, an iron thread that can support the fragile tales that are deposited in the territory you cross, in the landscape you admire, in the scents you feel, in the faces you meet, in the flavours you can taste, in the stories that are kept behind a door, in the crafts that resist, in the colours of the walls that you touch, in the variety of cultivated fields, in the coolness of a forest, in the footsteps of who before have in turn told those places" (Pileri et al. 2018). Line tourism has the potential to be "pedagogical narration for those who pass by and ontological for those who inhabit” (Pileri et al. 2018).

In 2010 a case study was born that is suitable for telling the narrative skills of the slow line. VENTO is a territorial project conceived and developed by a group of researchers from the Department of Architecture and Urban Studies of Politecnico di Milano (Italy), which is based on the power of the line: it is a cycle route that follows the Po river in northern Italy and connects Venice to Turin. In 2015, VENTO entered the Stability Law (Law n. 208 of 28/12/15, art. 1 paragraph 640), being recognized as one of the priority cycle paths of the National System of Tourist Cycle Routes (consisting of Ministry of Infrastructure and Ministry of Cultural Heritage), and it is 
arrived today to the feasibility project. $700 \mathrm{~km}$ of cycle path passes through villages and small municipalities in depopulation. Italy is a country of villages, where the $70 \%$ of Italian municipalities can be defined as "small" (i.e., with less than 5,000 inhabitants, according to the official definition of National Association of Italian Municipalities), and cover the 54\% of the territory (IFEL 2011; Pileri and Granata 2014; Casa e Pileri 2017). Furthermore, according to the National Strategy of Inner Areas, more than $60 \%$ of the Italian territory is occupied by inner areas, defined as "areas significantly distant from the centres offering essential services, but rich in important environmental and cultural resources and highly diversified by nature" (SNAI 2013). The scarce offer of services (education, mobility and health care), accessibility and job places is the effect of a series of different dynamics that have determined the uneven development between city and countryside, mountains and plain, coast and hinterland (Marchetti et al. 2017; De Rossi 2018).

These territories ask to not be forgotten and look for new possibilities for rebirth. VENTO tries to work for them, setting the goal of "sew up beauty of the territories crossed, reviving their vitality" (Pileri et al. 2018). This is how VENTO hopes to narrate, educate, save. It aims to train people to be aware of contributing to triggering virtuous processes, recovering abandoned assets, activating new jobs and saving places from "an unjust destiny of oblivion" (Pileri et al. 2015).

Pazzagli spoke of beauty and associates it with the taste (Belpaese and Buonpaese, Pazzagli 2014). Around this concept, a new phase of development can be designed, which focuses on the quality of time, landscape, air, water, culture, food, life. All this is the philosophy of slowness. Nietzsche in "Human too Human" (1878) says: "the noblest kind of beauty is that which does not transport us suddenly, which does not make stormy and intoxicating impressions (such a kind easily arouses disgust), but that which slowly filters into our minds". The adage philosophy is the main ingredient for the narrative power of VENTO, which uses slowness as a lens of knowledge. Here the narrative project looks for new forms with which to give voice to the places crossed, allowing them to tell their proper story. Local stories or popular wisdom, words, memories, phrases, proverbs, recipes, trades, can find space. They are Individual letters related to each other that a thread can tie together in a speech (Pileri et al. 2018). In this sense, the antifragile capacity of narration is fully realized, making the hidden identity patterns recognizable, revealing and enhancing the characters of beauty, and generating jobs through new local microeconomics.

Therefore, we talk about an action that has the power to be multifaceted and culturally and socially powerful. A sustainable, responsible, ethically oriented tourism (Nocifera et al. 2011; Pavione 2016), able to use narration to impart an education for caring and protection. This suggests the possibility of a tourism that reverses the concept of heritage, from something that is consumed to something that contains us (Montanari 2014), to be taken care of in the most emotional sense of the term. It will be a narrative tourism that is capable of educating and training, caring for and having care, repairing and regenerating, giving vision and changing horizons. 


\section{VENTO in the Casale Monferrato Area}

We said that VENTO crosses $700 \mathrm{~km}$ of small towns, many stories, tangible and intangible heritage, that require attention. We are talking about a territory that asks to find a new identity, thanks to a research opportunity with the Province of Alessandria, in the Piedmont region.

We are in the VENTO section that falls within the Province of Alessandria, a predominantly agricultural area which includes 16 municipalities: the most populated municipality, that is Casale Monferrato (34,812 inhabitants), the second most populated, that is Valenza (18,634 inhabitants), and other 14 small municipalities around them, with less than 2,000 inhabitants and in the depopulation phase (12 out of 16 have a negative population variation rate; data source: ISTAT 2001-2013).

In particular, here we will consider the municipality of Casale, as the most reference point for this territory in terms of cultural identity and economic system, even if in constant depopulation. In 1981 Casale had 41,899 inhabitants; in 1997 there were 37,493 inhabitants; in 2019 there were 34,812 inhabitants (source: ISTAT). The municipality of Casale Monferrato has an extension of $86.21 \mathrm{~km}^{2}$ and is located between the cities of Vercelli, Alessandria, Asti and Novara, in the industrial triangle of large cities of Turin-Genoa-Milan.

From a geographical point of view, Casale extends over a flat area located at the foot of the Monferrato hills, crossed by Po river and manned by "Po Park Vercellese Alessandrino". Recalling what Turri described as landscape icons, or "elementary units of perception" (Jodice and Turri 2001), the image of the local landscape is given by some characterizing elements: the most common crops, namely, rice fields, poplars and arable land; the local building typologies, first of all the Cascinas (farmhouses of northern Italy) and some mills still partially functional; native flora and fauna.

Even from an economic point of view, Casale is located at an intersection.

There is the historical economic activity of the place, that of rice cultivation, linked to the irrigated landscape of the rice fields. Then, there is the wine-growing activity of the hills, which has long been in decline due to the abandonment of marginal land. But the main economic activity of the place is the production of cement, which has also generated the most incisive identity image. For many years Casale has been known for the presence of the Eternit factory, now in disuse, which dispersed asbestos dust in the surrounding environment. From the 1950s to the present day, the inhalation of this material has caused more than 2,500 deaths and even today there is a high mortality rate attributed to Eternit among people born in the late 1980s, when the factory was dismantled. The phenomenon, in addition to the roofs of houses, sheds, churches, also affects the streets. All the streets of the municipalities near Casale were paved with this material, even if covered with a thin layer of asphalt. The long legal path is still ongoing with the "Eternit Bis" trial, which takes place in four separate forums, and the charge is of multiple aggravated manslaughter. Meanwhile, the peak of dead is expected from 2020 onwards, even if the decontamination is continuous.

Casale does not want to forget the drama, but at the same time it asks for a possibility of reborn. 
To understand how narration can be salvific and can trace new and regenerative identity patterns, a survey was conducted that uses VENTO as an opportunity to discover new stories to tell. In this sense, a Food Heritage Map has been created, whose VENTO thread is the reference narrative system (Fig. 1, built starting from Novellini 2002 and Barbero 2002). The map collects the food heritage, both as local raw materials, determined by the climate and the conformation of soils (for example, due to the presence of the river: amphibians, molluscs and fish), both as recipes and products linked to the Piedmontese territory (Krumiri biscuits, bagna cauda, agnolotti Casalesi, etc.).

This map has food as protagonist but it also contains the many ways of preparing it (result of the countless hybridizations), the stories of those who prepare it and the landscapes that produced it. All of these factors become a single territorial intangible heritage.

Then there is a second Map (Fig. 2, built starting from Barbero 2002), which tells different fragments of the intangible heritage linked to the rural world. A world of stories, of folk dances and songs, of proverbs related to country life, of festivals and customs.

There is the Mondina figure, very common in northern Italy between the end of the nineteenth century and the first half of the twentieth century, now disappeared. She was a seasonal worker in the rice fields which, during the flooding of fields from late April to early June, they were staying for whole days with water up to their knees, barefoot and with a curved back to remove the weeds that grew in the rice

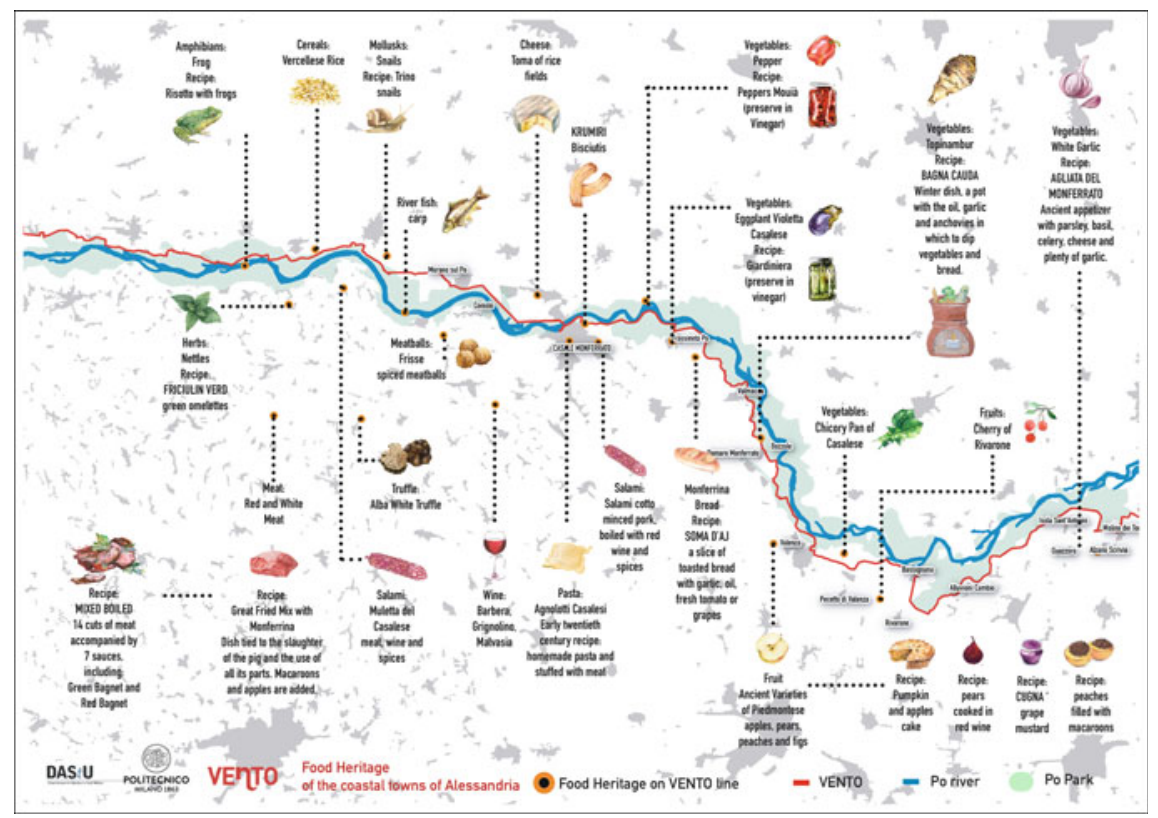

Fig. 1 Food heritage map. Elaboration of the author, 2019 


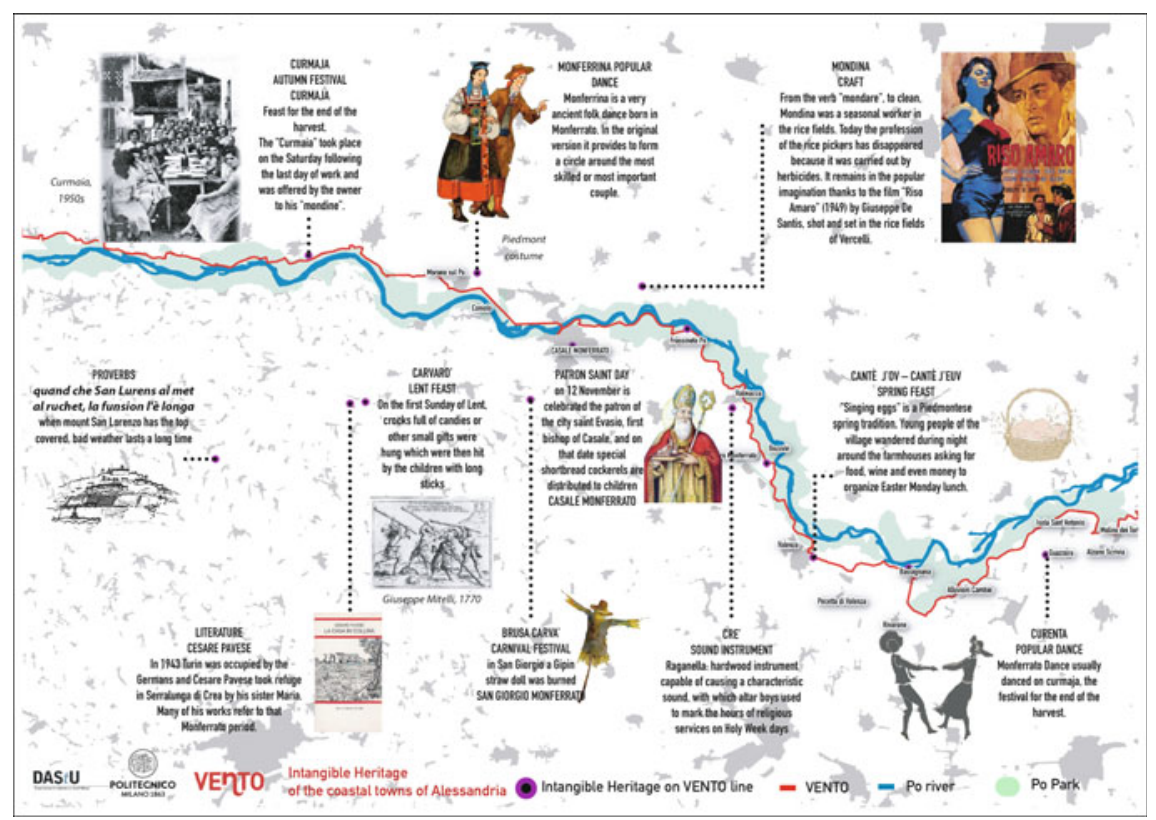

Fig. 2 Intangible heritage map. Elaboration of the author, 2019

fields. It was a tiring job, with bad working conditions. The 1949 film "Riso Amaro", directed by Giuseppe De Santis, draws a portrait that has become iconic, set and shot in the nearby rice fields of the near town Vercelli.

In the same map, along the VENTO thread, we meet the places of the literature of Cesare Pavese, who for a time lived in the village Serralunga di Crea, near Casale (in the period 1943-1945). "Perhaps the sad and closed walk through Crea told you symbolically more than many people, passions and things of these months. Of course, the myth is a discovery of Crea, of the two winters and of Crea's summer. That mountain is completely impregnated by it" (from "Mestiere di Vivere", 1952).

There are many possibilities of new images for these places and it is evident that what can improve them is the narration, and the slow line of VENTO can become the main activator of this narration.

However, these maps represent an exercise that can be extended to other territories and routes, with a view to a project that is not commercial, such as a simple tourism project, but pedagogical, such as free lines. Lines such as VENTO allow us to put in order all the material of territory by making it speak for itself and by making it available to a genuine narration.

Therefore, the design of the line can be multifunctional: it can help the reading of the original geographies; can reveal and tidy up forgotten heritage elements; it can become a thread that embroiders, restores broken tales and attracts pedagogical tourism to educate, care for and generate jobs for new sensitive economies. 


\section{Lesson Learned}

Saramago says that "the journey never ends. Only travelers end. And they too can extend in memory, remembrance, narration" (from "Viagem a Portugal", 1981). That's why narration is important: to continue living and making people live through memory. The etymology of narration (from latin gnoscere) suggests the notion of knowing and making known. Narration produces knowledge and "to know is an infinitive verb" (Granata et al. 2013). And the magic of narration is endless, since it is capable of creating heritage of memories from single objects and providing, to those who have listened to them, the magnificent opportunity to keep them alive by becoming their new custodian.

Pasolini in 1975 said "defend the mulberry pickets, the alder, in the name of the Gods, Greek or Chinese. Die for your love of vineyards. (...) Defend the fields between town and countryside, with their abandoned cobs. Defend the meadow between the town house and the canal. (...) defend, protect, pray!" (Pasolini 1975). "Saluto e augurio" (1975), originally in Friulian dialect, is a testament addressed to a bourgeois boy, a student who still loves the ancient knowledge that his peers have rejected. Pasolini asks precisely to an interlocutor distant from his way of being to defend the past and all values that belong to the agricultural world that is being lost. "Defend, protect, pray" are actions of a project for a revolution of will (defend), of mind (protect) and of soul (pray). It is a project that addresses the furthest interlocutor, since those who do not know have the opportunity to preserve an almost disappeared heritage, handing it down.

Also Vito Teti reminds to the reader a relationship based on soul and on a sense of plural belonging: "We are our body, our family, our ancestors, our history. We are the place where we were born and raised and the inhabited, known, lived places. The places dreamed and desired; but also places we fled from, or despised, loved and hated places. The concept of place cannot be simply understood in terms of space: (...) every place is mental and requires a symbolic organization that has to do with time, memory and oblivion" (Teti 2018).

What is common to thoughts of Pasolini and Teti is that for both each of us can become the narrator of "what remains" (Teti 2017) and create "minimalist utopias (..) even without heroes" (Zoja 2013).

All this described up to now is a store of reflections, potential and hopes that asks to be realized by individuals, by community, by local administrations, beyond the media banality of typical products, festivals and folklore. We must work together for material and immaterial heritage, recognized and unrecognized, inside and outside museums, universities, libraries, archives, to reconstruct a new, powerful, intentional and antifragile narration. It will be a narration able to show that the knowledge that we thought dead, actually it is alive and is capable of including individuals, uniting the community, generating sensitive economies and is capable of reconstituting a past history knowing how to contain the future one. 


\section{References}

Archivio Diaristico Nazionale. http://archiviodiari.org. Accessed 2 Jan 2020

Barbero A (2002) Camminare il Monferrato. Guida al trekking in Monferrato in 40 percorsi. Editrice il Monferrato, Villanova Monferrato

Bernardelli A (1999) La narrazione. Laterza

Bodo S, Mascheroni S, Panigada MG (2016) Un patrimonio di storie. Mimesis Edizioni

Brunelli M (2011) Heritage interpretation. Un nuovo approccio per l'educazione al patrimonio. EUM, Macerata

Casa M, Pileri P (2017) Il suolo sopra tutto. Cercasi "terreno comune": dialogo tra un sindaco e un urbanista, Altreconomia, Milano

De Rossi A (2018) Riabitare l'Italia. Le aree interne tra abbandoni e riconquiste. Donzelli Editore, Roma

Donadieu P (2013) L'immaginario dei territori agrourbani o la terra ritrovata. Scienze del territorio 1/2013. Firenze University Press

Granata A, Granata C, Granata E (2013) Sapere è un verbo all'infinito. Ed Il margine. Trento

Herzfeld M (2011) Cultural intimacy. Social poetics in the nation-state. Routledge

IFEL (2011) Atlante dei piccoli comuni. Fondazione IFEL, Roma

Jodice M, Turri E (2001) Gli iconemi: storia e memoria del paesaggio. Electa, Milano

Longo G (2008) Il senso e la narrazione. Springer

Marchetti M, Panunzi S, Pazzagli R (2017) Aree interne. Per una rinascita dei territori rurali e montani. Rubettino Editore, Soveria Mannelli

Montanari T (2014) Istruzioni per l'uso del future. Il patrimonio culturale e la democrazia che verrà. Minimum Fax

Museo dell'Antica Grancia. http://www.museisenesi.org/musei/museo-dellantica-grancia-e-del lolio.html. Accessed 2 Jan 2020

Museo della Guerra 1914-1918 di Passo Fedaia a Canazei, http://www.lagrandeguerra.net. Accessed 2 Jan 2020

Nietzsche F (1878) Umano troppo Umano

Nocifera E, de Salvo P, Calzati V (2011) Territori lenti e turismo di qualità. Prospettive innovative per lo sviluppo di un turismo sostenibile. Franco Angeli, Milano

Novellini S (2002) Dispensa del Po. I sapori del grande fiume. SlowFood

Pasolini P (1975) La nuova gioventù. Garzanti, Milano

Pazzagli R (2014) Il Buonpaese. Territorio e gusto nell'italia in declino, Felici Editore

Pavese C (1952) Il mestiere di vivere: diario 1935-1950

Pavione E (2016) Turismo sostenibile e valorizzazione del territorio. Sfide e opportunità di sviluppo del cicloturismo in Italia. Aracne Editrice, Ariccia (RM)

Pileri P, Giacomel A, Giudici D (2015) VENTO. La rivoluzione leggera a colpi di pedale e paesaggio. Corraini Edizioni

Pileri P, Giacomel A, Giudici D, Munno C, Moscarelli R, Bianchi F (2018) Ciclabili e cammini per narrare territori. Ediciclo Editore, Portogruaro (VE)

Pileri P, Granata E (2014) Piccoli comuni, grandi responsabilità. In Bonini G. e Visentin C. (A cura di), Paesaggi in trasformazione teorie e pratiche della ricerca a cinquant'anni dalla Storia del paesaggio agrario italiano di Emilio Sereni, Editrice Compositori, Bologna

Recalcati M (2014) L'ora di lezione. Per un'erotica dell'insegnamento. Super et opera viva

Salerno I (2013) "Narrare" il patrimonio culturale. Approcci partecipativi per la valorizzazione di musei e territori. Rivista di Scienze del turismo, 1-2/2013

Saramago J (1981) Viagem a Portugal

SNAI (2013) Strategia Nazionale per le Aree Interne. http://www.programmazioneeconomica.gov. it/2019/05/23/strategia-nazionale-delle-aree-interne/. Accessed 14 December 2019

Teti V (2017) Quel che resta. L'Italia dei paesi, tra abbandoni e ritorni. Donzelli Editore, Roma

Teti V (2018) Il sentimento dei luoghi, tra nostalgia e futuro, in De Rossi (a cura di) Riabitare l'Italia. In: Le aree interne tra abbandoni e riconquiste. Donzelli Editore, Roma 
Tornatore JL (2011) L'inventaire comme deni de la recon- naissance. In Bortolotto, Chiara (sous la direction de), Le patrimoine culturel immatériel, enjeux d'une nouvelle catégorie. Editions MSH, Paris

Yourcenar M (1951) Mémories d'Hadrien suivi de Carnets de notes de Mémories d'Adrien. Librairie Plon, Paris

Zagato L (2014) Diversità culturale e protezione/salvaguardia del patrimonio culturale: dialogo (e contaminazione) tra strumenti giuridici. In Cataldi G, Grado V (a cura di), Diritto internazionale e pluralità delle culture. Editoriale scientifica, Napoli, pp 369-388

Zingari V (2015) Patrimoni vitali nel paesaggio. Note sull'immaterialità del patrimonio culturale alla luce delle Convenzioni internazionali. In Zagato L, Vecco M, a cura di. Citizens of Europe. Culture e diritti

Zoja L (2013) Utopie minimaliste: Un mondo più desiderabile anche senza eroi. Chiarelettere Editore, Milano 